\title{
Message from the President-in-office Michel Temer on the occasion of the centenary of the Revista de Medicina of the University of São Paulo's School of Medicine
}

Tn this moment in which the Revista de Medicina of the University of São Paulo $\mathrm{S}$

School of Medicine reaches its centenary, I am pleased to join the celebration of such a significant date.

Founded in 1916 by Arnaldo Vieira de Carvalho, the Revista de Medicina is considered to be the oldest academic scientific journal in the world which is still in circulation. Its main goal is to bring students closer to the world of scientific production as well as to provide greater integration between professors and students.

It is necessary to emphasize the importance of this publication to the academic life of the Universidade de São Paulo, where I graduated from Law School, and which is our largest university institution, worldwide renowned. The founder of the USP's Medical School, Dr. Arnaldo Vieira de Carvalho, expressed in the preface of the first issue his wish that the students would actively participate in the production process of the journal, keeping it alive the dissemination of science along with it.

Dr. Arnaldo's words were premonitory, for one hundred years later the tradition remains, and in accordance with the modern technology that science offers us each day, the entire collection of the Revista de Medicina is digitally available for consultation to this and to future generations.

Michel Temer

Acting President of the Republic 


\section{Mensagem do senhor Presidente em exercício Michel Temer por ocasião do centenário da Revista de Medicina da Faculdade de Medicina da Universidade de São Paulo}

To momento em que a Revista de Medicina da Faculdade de Medicina da Universidade de São Paulo chega ao seu primeiro centenário, é com satisfação que me junto às comemorações de tão significativa data.

Fundada em 1916 por Arnaldo Vieira de Carvalho, a Revista de Medicina é considerada a publicação científica acadêmica mais antiga do mundo ainda em circulação e tem como objetivo principal aproximar os alunos do mundo da produção científica, além de propiciar maior integração entre professores e alunos.

É necessário ressaltar a importância dessa publicação para a vida acadêmica da Universidade de São Paulo, na qual me graduei no curso de Direito, e que é a nossa maior instituição universitária, reconhecida mundialmente. O doutor Arnaldo Vieira de Carvalho, fundador do curso de Medicina da USP, no prefácio da primeira edição, manifestava seu desejo de que os alunos participassem ativamente do processo de produção da revista, mantendo-a viva, e, com ela, a disseminação da ciência.

As palavras do Dr. Arnaldo são premonitórias, pois, cem anos depois, a tradição permanece e, em consonância com a modernidade tecnológica que a cada dia nos oferece a ciência, todo o acervo da Revista está disponível digitalmente para consulta desta e de futuras gerações.

Michel Temer

Presidente da República, em exercício 